\title{
Newly arrived pupils and violence: A CDA analysis of political advices regarding strategies and responsibilities for various actors in Swedish education
}

Silvia Edling, Guadalupe Francia

\begin{abstract}
In the Convention of the right of the Child (CRC) it is stated that all children should be protected from all kinds of violence. However war, social conflicts and climatic catastrophes have placed immigrant children at risk to object for violence. The purpose of this paper is to study how Sweden politically advice actors within the educational field to approach newly arrived pupils in education by placing it in relation to research about violence. What is particularly payed attention to in the policy document is need to oppose the following risks: b) being in risk of exclusion, c) facing perceptions of assimilation, and f) a lack of clear responsibilities amongst the actors assisting the immigrant children. A fuzziness of responsibilities is at time created with concepts such as "the school should". Education for the Other is the most dominant strategy emphasizing that the newly arrived child's needs in education should be recognized as well as the importance to distribute what is lacking to promote the pupil's development. The advices do not say anything about the content of knowledge required amongst various actors in order to do analysis of processes. [1170]
\end{abstract}

Keywords: children's right, violence, educational policy, newly arrived pupils, otherness.

\section{Introduction}

Violence in form of war, social conflicts and climatic catastrophes has forced about 21.3 million people from their home. Over half of these refugees are under the age of 18 (UNHRC, 2016). Both children with and children without families are considered as one of the most vulnerable group of people in need of special protection (European Commission 2015). As an strategy to protect children from all form of violence the Convention of the Right of the child (CRC) stipulated that children need to be protected from “... all forms of physical or mental violence, injury or abuse, neglect or negligent treatment, maltreatment or exploitation, including sexual abuse, while in the care of parent(s), legal guardian(s) or any other person who has the care of the child". 
Starting from a broad conception of violence the CRC emphasizes the need to develop strategies against both active violence (such as injury, abuse, maltreatment, and exploitation), as well as passive violence (legation in relation to guarantee the right). By ratifying the CRC in 1989, Sweden is engaged to ratify the CRC to guarantee that child needs in education are achieved by all means at hand (prop., 2009/10:232). One of the central rights stipulated by the CRC is Education. By defining Education as a basic human right the CRC claims for then need develop strategies against both active and passive violence at the school practices. Furthermore, the Convention on the Right of the Child that states that education is a basic human right The Refugee Convention from 1951, signed by 144 state parties, equally emphasis the importance of securing education to all children - including refugees (UNHCR, 2011).

However in times of war, socio-economic crisis, and climatic catastrophes Education is often neglected. Therefore this paper aims to develop scientist knowledge about refugee children's' right to qualified education in times of global conflicts. With this purpose of this paper is to study how Sweden politically advice actors within the educational field such as heads, teachers, personnel, and principles to approach newly arrived pupils in education by placing it in relation to research about violence. The questions asked are as follows: a) How are the newly arrived pupils described in the educational policy document, b) how is/are the responsibility(-ies) defined between various actors in education, c) what kind(s) of solution(s) to welcome them in education is/are proposed, and d) how do the findings correspond with research about violence? The paper is divided into four parts: (i) a background section, (ii) a methodological section, (iii) results, and (iiii) conclusions.

\section{A background}

In this section a short background of the study is presented. To begin with a definition of violence and strategies to oppose violence in education are fleshed out. The situation for newly arrived pupils in Sweden is described based on statistical analysis and policy guidelines are thereafter described. Thirdly, a research over-view is offered containing of risks that is important to pay regard to when welcoming immigrants into the Swedish society. Finally, strategies to oppose violence (referred to as oppression) in education are presented. The risks and strategies to oppose violence are used as analytical tools to interpret the content of the policy document studied in this paper.

\section{The concept of violence}

In this paper violence is used in a broad sense interconnecting various occasions in which children are being or are in risk of being hurt psychically 
and physically (Hamby \& Grych, 2013), such as bullying discrimination, harassment, and violation (cf. Greeff \& Grobler, 2008; Parkes, 2007) through the introduction of the Discrimination Act (SFS, 2008, p. 567) and the paragraph regarding Other violating treatment expressed School Act (SFS, 2010 , p. $800, \S 6)$ there are investigations highlighting that immigrant children who have arrived in Sweden experience physical violence in that they are forced to exist under a constant threat to be deported. From this follows that it becomes important to acknowledge how policies oppose or stimulate a "climate of violence". That is to say how the procedures and practices they express in school influence vulnerable individuals or groups of individuals in various ways. In relation to this it becomes important to pay attention to how conditions are designed to facilitate and/or obstructing learning (Epp \& Watkinsson, 1997).

There are patterns of violence that are similar in-between various contexts: bullying, discrimination, exclusion, oppression, homophobia, marginalization and so forth (Hamby \& Grych, 2013). One example of such interconnecting link is otherness or difference. In other words, when violence occurs, it generally does so in relation to those who diverge from the norm in any sense. The acceptance of violence seems to increase when it becomes accepted to ignore or loath those who differ from the norm (see for instance, Allport, 1954; Kumashiro, 2001; Nussbaum, 2012; Waghid \& Nuraan, 2013; Young, 1990; Žižek, 2008). Difference can both be understood as group or cultural differences and as an individual difference in the sense that everyone is unique and irreplaceable (Mouffe, 2000). Another interconnecting link between different forms of violence is the need to coordinate various elements to work towards the same goal in order to oppose systematic violence (Epp \& Watkinsson, 1997; Miller, 2002) This can be described as a holistic or sustainable approach that demands a movement and attention to how factors such as social patterns, economical patterns, and environmental patterns are co-dependent and set the condition for human relations (cf. Ketschau, 2015; Pinar, 2007).

\section{Swedish context}

Currently, Sweden is one of the EU-members that have one of the highest first time asylum and most of the people coming from Sweden are from Afghanistan (6762), Eritrea (1625), and Syria (1953)1. The statistical analysis from the Bureau of Immigration from autumn 2015 shoes that 70.000 (ca 50\%) of the 160.000 immigrants seeking asylum in Sweden were under the age of

\footnotetext{
${ }^{1}$ http://www.migrationsverket.se/download/18.27485d6514fa83199cf1e8b/1444401856800/ Aktuellt_om_ensamkommandebarn_okt2015.pdf [160608].
} 
eighteen. Of these 70.000 children 35.000 (ca50\%) came here alone without any adult guardian. The pressure on the Swedish society with the work to welcome immigrants increased with $400 \%$ compared to the year before ${ }^{2}$.

The infrastructure in Sweden to handle immigrants is highly complex. The public sector consisting of various levels (state, county, and municipals) are interlaced with the private sector (civil actions in form of donations, voluntary work, sport centers etc.) in that the public sector actively encourages the civil society to take responsibilities for the newly arrived pupils by offering state money to private actors. It is vital to remember that the educational system which is in focus in this paper, is only a tiny aspect of this complex infrastructure that need to cooperate with social department social services, health care system, and civil society (Zetterqvist Nelson \& Hagström, 2016).

Several documents guide actors' responsibilities to handle newly arrived pupils in school: a) general advices about education for newly arrived pupils, b) language introduction, c) national over-view materials, d) successful factors when it comes to organize newly arrived pupils' education, e) the Swedish language for newly arrived pupils, f) supportive material in the mother tongue, g) supportive material for assessment in Swedish and Swedish as a second language. In this paper the advisory policy document General advices about education for newly arrived pupils is used as a base for analysis.

\section{Seven challenges to welcome immigrant children into Swedish society}

The research about these risks and possibilities are covered in a large report from the FORTE [A research council for health, work-life, and wellfare in Sweden] (Zetterqvist Nelson \& Hagström, 2016). The seven interlaced challenges highlighted by research can be summarized in the following manner: a) psychical violence of waiting for the long asylum process to end, b) being in risk of exclusion, c) facing perceptions of assimilation, d) risk of forgetting the need of children with adult guardians, e) gap between publicand private sector, f) a lack of clear responsibilities amongst the actors helping, and g) overlooking the contextual framework that various actors supporting immigrant children take part in (ibid.).

To begin with, (A) immigrant children are a vulnerable group in general in that they often come from violence: war, terrorism, and so forth that risk marking them for life and creating severe traumas. Although, they arrive to a safer country the long waiting processes with the asylum risks creating

\footnotetext{
${ }^{2}$ https://www.migrationsverket.se/Om-Migrationsverket/Statistik/Asylsokande---de-storstalanderna.html [170131].
} 
psychical violence in the very insecurity of not knowing how the future will turn out. Secondly, (B) immigrant children are in risk of being 'othered', i.e. regarded as different from the norm in ways the reduces their life conditions compared to children who stem from families who has lived in Sweden for a long time (Kumashiro, 2000). A broad range of research shows that it becomes of utmost importance to include the immigrant children into society as soon as possible (Andersson, Ascher, Björnberg \& Eastmond, 2010; Ascher \& Hjern, 2013). Often immigrant children are placed in preparation classes in school, isolated from Swedish children in ways that comes with negative consequences socially and educationally (Nihad Bunar, 2010; Nihad Bunar, 2015).

Thirdly, $(\mathrm{C})$ research indicates that perceptions of assimilation, that is an idea that immigrant children should cast their previous cultures beside in order to fully adapt to the 'Swedish society' is problematic in that it makes inclusion more difficult. The process of inclusion is stimulated by strategies that allow various perspectives, ways of being, and view-points to take space in public arenas (Hertzberg \& Sundelin, 2014; Wernesjö, 2014; Åhlund, 2015).

Fourthly, (D) it is pointed out from various directions that immigrant children who come to Sweden with parents are more vulnerable than children who come alone in that they risk falling between chairs. It is assumed that the parents or the adults they come with have the strength, capability, and will to help the children in ways needed (Çelikaksoy \& Wadensjö, 2016; Eastmond \& Ascher, 2011; Wernesjö, 2014).

Fifthly, (E) there are numerous research reports stressing that the link between public and private sectors in education increase the wellbeing of immigrant children. Particularly, sport organizations can facilitate the inclusion of immigrant children in that they create situations where the children are naturally included in a commonality with others striving towards the same aims (Hertting \& Karlefors, 2013). Sixthly, (F) psychical and physical violence increase when the responsibilities between actors are fuzzy. From this perspective, it becomes important the clearly establish who is responsible for what (Nihad Bunar, 2010; Wernesjö, 2014). Finally, (G) various actors in society exist within specific contextual structures that need to be taken into account (Nihad Bunar, 2010; Wernesjö, 2014; Åhlund, 2015). Seeing that the immigrant and refugee child generally is regarded as 'the Other' in society we turn to Kevin Kumshiro's four strategies in education.

\section{Four strategies to handle the 0ther in education}

Kumashiro (2000) describes four strategies used to approach the needs of those who diverge from the norm (the Other) in education, which all are 
based on a particular understanding of diversity and come with their specific advantages and disadvantages. This analytical framework is also useful in analyzing and framing policy aimed at responding to cultural difference. The four strategies are: a) Education for the Other, b) Education about the Other, c) Education that is Critical of Privileging and Othering, and, d) Education that Changes Students and Society (ibid.).

A frequently used strategy to support the needs of Others in education is to actively work to contest prejudices and to create welcoming environments [Education for the Other]. One approach linked to education for the Other is to strengthen the sense of safety at the school, by discussing how one should treat Others as well as creating rules and structures striving to secure their wellbeing. Besides safety, recognition is mentioned as another approach to meet the needs of Others in education. This implies that it is important to listen to Others and include their view-points in education, Thirdly, distribution of necessary goods and values is an essential approach to come to terms with plausible problems attached to Otherness. It can be in form of improving buildings, giving economic support to teachers, hand out computers and so forth. The distributive dimension also includes establishing groups and smaller communities in school in which minority groups are represented and where they can make their voices heard (Kumashiro, 2000).

Whereas this strategy aims to help those who diverge from the norm the strategy Education about the Other shifts focus to the idea that knowledge about Others will provide with a better platform to guarantee Others' needs. Another common way to approach the needs of Others is to teach children and youth about the Other (Education about the Other). The strategy is based on a belief that educators generally handle knowledge in an uncritical fashion hence excluding various ways of approaching the world thereby maintaining and creating gaps between norms and norm abbreviations as well as prejudices of those who diverge from the norm. To solve this problem several approaches are suggested. To begin with schools should strive to include knowledge about marginalized groups, such as knowledge about apartheid, women's emancipation movement, and Muslim communities. Secondly, it is important not to reduce education about Others to particular days in the year, but constantly include it in day-to-day education (Kumashiro, 2002b). The focus in this approach is to provide knowledge about the exposed and vulnerable Other in order to decrease prejudices and a negative attitude to those who are different, subsequently transferring the norm abbreviations to something normal, for example "newly arrived children are humans too and they not dangerous" (ibid.).

While both education for and education about targets the Others in different ways there is a third strategy shedding light on social processes rather than 
specific groups. There are those who maintain that knowledge about, for instance, refugees is insufficient when it comes to meet the needs of Others. What is forgotten, according to this standpoint, is the way diversity is produced in norms and structures pervading daily life and hampering some groups' possibilities (see also Ellsworth, 1989; Giroux, 1988; Hooks, 1990) to exist as equals. The strategy [Education that is critical of privileging and Othering], stemming from critical pedagogy and Freire directs attention to ongoing questions involving the individual's relation to norms, structures and ideologies, such as: who is excluded in text-books, what ideas or ideologies are rights and regulations governing school based on, what is valued and devalued amongst teachers and children. By making teachers and young people become aware of norms and structures, then it becomes possible to change one's perceptions and actions in ways that better correspond to the Other's needs. Examples of advantages according to Kumashiro (2000) are that educators do not focus upon helping and gaining knowledge about certain groups, but rather pays regard to the production and reproduction of norms involving everyone. It acknowledges that statements expressed in for instance guidelines, curriculum, and laws are not neutral and hence encourages the necessity to highlight different ways of seeing and a critical awareness regarding norms and norm abbreviations. Examples of disadvantages are that the strategy takes for granted that certain norms and structural patterns have the same effect on everyone, which research has shown is not the case. Human life is too complex and dynamic to be captured with concepts such as hegemony and ideology (see also Bansel, Davies, Laws \& Linnell, 2009; Ekerwald \& Säfström, 2012; Kumashiro, 2001; Walkerdine, 1989). Finally, it is also taken for granted that a critical awareness about the production and reproduction of norms and values automatically generates responses to Others that secure their needs and do not harm them. Being aware of a phenomenon does not mean that I accept them or that unconscious reactions towards Others will not emerge that impede on their well-being.

In order to capture complexity there are those advocating for a strategy that pay regard to the dynamics and complexity taking place in everyday life. While the previous strategy separates between people's daily actions and norms, Education that changes pupils and society does not make a clear cut distinction between structures, norms and people's actions. Laws, textbooks, daily speech are all human made and already infused with a specific interpretation and world view. Structures are woven through human patterns that are created in daily actions, speech (including body language) and the production of written texts. People's perceptions and meaning-making is accentuated as a central means to shape society in different directions and hence directs attention not only to interpretations of rights and regulations 
but to the seemingly minor and trivial meetings taking place between humans, including teachers and pupils. Rather than taking the beginning in structures fixing groups as victims or conquerors the fluctuation of daily power-relations are highlighted, which makes it possible to capture moments when an individual's possibilities to influence alters from situation to situation. These encounters are not always easy but rather conflict-loaded when different interpretations collide or/and when subconscious reactions and prejudices color meaning-making and risk hurting people in the kindest of intentions (Kumashiro, 2000; see also Edling, 2009).

\section{Methodology}

In this paper the advisory policy document General advices about education for newly arrived pupils (GANAP) (The Swedish National Agency of Education, 2016) is used as a base for analysis ${ }^{3}$. In the policy document General advices about education for newly arrived pupils it is stated that children previously living in another country and who are between 7-16 years of age should be referred to as newly arrived children. Newly arrived children are refugee children, children who have 'tidsbegränsade uppehållstillstånd', and children of a parent belonging to a foreign country. In order to belong to the group 'newly arrived pupil' the child needs to have started her or his education during autumn, the same year s/he turns seven. After four years of education in Sweden the pupil should no longer be referred to as newly arrived pupil (The Swedish National Agency for Education, 2016, pp. 11-12). The political advices encompass both the obligatory school forms (elementary schools, grundssärskolan, same school, and special school) and upper secondary high school. The advices in the document are directed to the principle, teachers and school personnel in general (The Swedish National Agency of Education, 2016). It is pointed out that regulations should be followed but that alternative strategies are allowed as long as they fulfil the purposes.

The analysis draws on a Critical Discourse Analysis (henceforth, CDA). CDA is a methodological approach to dissect language, words and semiotics in order to study the content of language patterns and their consequences for human action (van Dijk, 1995). Based on Fairclough (1992, 2000) we argue that CDA allows us to understand the dialectical relation between discourse and social practices when analyzing strategies to approach newly arrived pupils in education. It is here argued that the usefulness of CDA is that it makes

${ }^{3}$ http://www.skolverket.se/skolutveckling/larande/nyanlandas-larande/nyanlandas-larande1.237656 . 
it possible to include the perspective of agency in the analysis. Faircloughs' $(1995,2004,2013)$ CDA was used as a theory and methodology to analyze, interpret and translate the material in these policy documents. What are particularly studied in the document are the parts where descriptions of newly arrived pupils, responsibilities for various actors and strategies for education are described. These parts have been highlighted and the use of words and semiotics has been analyzed in relation to purpose. Following Fairclough (2000) the interpretation of the empirical data includes three different dimensions: a) text analysis (description), b) processing analysis (interpretation), and c) social analysis (explanation). In our study these dimensions correspond to our research questions:

a) How are the newly arrived pupils described in the educational policy document? (description)

b) How is/are the responsibility(-ies) defined between various actors in education? (description)

c) What kind(s) of solution(s) to welcome them in education is/are proposed? (description)

d) How do the findings correspond with research about violence? (interpretation and explanation)

The descriptions are placed in relation to research about immigrants in Sweden stressing seven risks to be aware of and Kumashiro's for strategies in order to interpret and explain the description.

\section{Results}

In this section the results of the analysis of the policy document is presented. The results are organized by beginning with describing, interpreting and explaining descriptions of newly arrived children and thereafter strategies and responsibilities of various actors in education.

Descriptions of newly arrived pupils: Same obligations and rights as other pupils

It is stressed at several occasions that newly arrived pupils "are obliged to follow the same regulations as all pupils". As such the newly arrived pupils are in a sense included in the same welfare system as other children and both have the right to get support when needed and use the "vocational guidance" and "health care facilities". "It is important to keep in mind that newly arrived pupils are obliged to follow the same regulations that as all pupils when it comes to for example the School's value- and knowledge mission, information about studies and vocational guidance, health care facilities for pupils, 
leadership, and stimulation as well as the schools compensatory mission" (GANAP, p. 13). At the same time the newly arrived pupils are also obliged to pay regard to and acknowledge the school's values and have the same demands on knowledge skills as the rest of the pupils.

\section{Descriptions of newly arrived pupils: Heterogenic group}

In the policy document the newly arrived children are frequently described as a heterogenic group. The discourse is created through words such as: "heterogenic group", "stay here under different conditions and relationships", and "their school background looks different" (GANAP, p. 11). The discourse corresponds with research about welcoming immigrant children into the Swedish society where it is pointed out that it is important to pay regard to the backgrounds of immigrants rather than treating them as a homogenous manner (see risk b) (Zetterqvist Nelson \& Hagström, 2016). Central in the research overview that Kumashiro conducted in 2000, the importance of handling otherness is an important pre-condition to oppose oppression that come into expression both structurally and in interpersonal relations. The notion of difference expressed in the policy document comes into expression in three different manners: a) categories of newly arrived people, b) cultural differences, and c) individual differences.

To begin with, it is pointed out that newly arrived pupils can be categorized as "immigrants", "asylum seekers", "paperless" (GANAP, p. 11) and so forth and that it is important to pay regard to this. Furthermore, it is stressed that the pupils' experiences from the previous country need to be taken into account "susceptible to... the knowledges and experiences/.../in relation to the school in the countries where the pupil has previously lived" (GANAP, p. 23). Finally, there is an individual dimension in the description of difference underlining the need to pay regard to the particular pupils "preconditions and needs" (GANAP, p. 28). Hence, the discourse concerning the view of the newly arrived pupil incorporates both an individual and a social dimension which can be linked to worldviews and strategies tied to a holistic or sustainable perspective.

Strategies and responsibilities of various actors in education: Important with a holistic perspective that requires constant consequence analysis

Central in the advices from political direction is to anchor the work with newly arrived children in a holistic perspective which can be compared to Kumashiro's (2000) fourth strategy: Education that changes pupils and society in the sense that it tries to take into account complexities and dynamics in everyday life. The document General advices about education for newly arrived pupils (GANAP) pointed out that "the work with newly arrived pupils needs to be a part of the school's [systematic] quality work just as any 
practice in school" (p. 17). This holistic discourse is created by interlinking and synchronizing various components such as: "a long term and well anchored plan" (p. 14), "organization" (p. 21), "pupil's pre-conditions and needs" (p. 30), "all-encompassing analysis" (p. 23), "creating a learning environment" (37), "resources" (p. 14), the inclusion of "relevant actors of the school" (p. 30), "follow ups" (p. 17), and "measures" (p. 17). The holistic approach is also supported by research concerning how to minimize violence when welcome immigrant children into the Swedish society in that it aims to pay regard to various aspects that are interlaced and risks harming immigrant children (Zetterqvist Nelson \& Hagström, 2016).

Research about welcoming immigrants into the Swedish society points out that it is important with a clear division of responsibilities amongst actors working with children (se risk f) (Zetterqvist Nelson and Hagström, 2016). The General advices about education for newly arrived pupils (GANAP) stipulates that he responsibility to create a long term plan for how to approach newly arrived children is in the hands of the head [huvudman]. This plan involves two main dimensions, namely an organizational one and a dimension outlining how the newly arrived pupil's knowledge development is to be taken into account. Directly under the head [huvudman] is the principle who needs to be involved in the establishing of the "long term plan" and analyze what kind of resources that are needed for the actors in school. The latter responsibility can be linked to risk $\mathrm{g}$, namely overlooking contextual framework that various actors exist in (Zetterqvist Nelson \& Hagström, 2016). Both the head and the principle are obliged to create the plan based on child consequence analysis which in term enhances the holistic focus (GANAP, pp. 17, 21). In other words, it becomes important to create plans and judgments based on how various parts work together and intersect. The organization at the school aiming to support newly arrived children is the responsibility of the principle, The pupil cannot be placed in a specific grade before the principle gives his or her consent (GANAP, p. 21). The teachers who operate under the head are obliged to take part in and analyze the documents of the child (GANAP, pp. 23-24) and build teaching in a sustainable manner stimulating deep-learning by not merely focusing on the pupil's fragmented knowledges in language but also how they use language in a larger context (GANAP, p. 29). The staff in general too "needs to make all-encompassing analysis of all the existing documents" (GANAP, pp. 23-24). At some occasions it is stated that "the school follow up their development" (GANAP, p. 30) or "the school also needs to take into consideration" (GANAP, pp. 23-24). In these cases the school is made an agent and as such renders the division of responsibilities fuzzy in that context (see risk f) (Zetterqvist Nelson \& Hagström, 2016). 
Strategies and responsibilities of various actors in education: Compensatory strategy

According to the General advices about education for newly arrived pupils (GANAP) the school's overall ambition to compensate for pupil's deficiencies also permeates the strategy to handle newly arrived pupils. The importance to compensate plausible shortcomings amongst newly arrived pupils reoccur in the text through words like: "compensatory mission" (13), "newly arrived pupil's needs cannot be fulfilled by one specific measure/.../need of extra adjustment" (p. 25), and [t]eachers must form and adjust all education to support and stimulate every pupil based on their preconditions and needs" (p. 28). No specific strategies to compensate the pupils are mentioned but are decided from case to case. This strategy can be compared with Kumashiro's (2000) Education for the Other that it focuses on the newly arrived pupil's needs by distributing what is lacking in order to improve the person's situation.

When it comes to the school's compensatory strategy "[t]he school's compensatory mission implies a consideration to pupils with special need" (GANAP, p. 13) rendering the responsibility division unclear (see risk f). It is only the teachers and the staff in general that are explicitly mentioned to have the responsibility to pay regard to if any compensation is required to fulfill the needs of newly arrived children (GANAP, pp. 25, 28). If a lack is detected they need to make adjustments. However, it is not clear who exactly needs to do these extra adjustments. In a sense the responsibilities are divided in the document which research points to is vital (see risk f), but there are also fuzziness in the division of responsibilities important to be aware making it indirectly important for the head and the principle to pay regard to.

Strategies and responsibilities of various actors in education: Inclusion in ordinary class important for participation

The concept "inclusion" occurs at several times in the document rendering it to be a discursive pattern that conveys a message about strategies for newly arrived pupils. Inclusion is described as something positive, through words in GANAP such as "[w]hen the pupils' take part in education together with the ordinary group it enhances participation" (p. 28) "included creates good conditions" (p. 28), and "important that/.../ newly arrived pupil [is] socially included" (p. 28). This strategy corresponds well with research about welcoming immigrant children into the Swedish society where it is pointed out that exclusion risks harming these children (see risk b) (Zetterqvist Nelson \& Hagström, 2016). Moreover, following Kumashiro's overview of strategies for those who are in risk of being othered this strategy can implicitly be compared with Education for the Other that amongst others involves recognizing the needs of newly arrived pupils in education. However the question of inclusion is 
not in the foreground in Kumashiro's four strategies, rather what he accentuates is how the Other is approached in or outside class and that is not defined in detail in this policy document.

The strive to include these children into ordinary education seems primarily to be the responsibility of teachers and staff in general (GANAP, p. 28). The importance of clear responsibilities is underlined in research about immigrants (see risk f) and there is a division of responsibilities in the document. However how the responsibility is to be understood amongst teachers and staff in general is not clearly stated and requires further elaborations.

Strategies and responsibilities of various actors in education: Informing newly arrived pupils and their legal guardians

Another central strategy is to inform newly arrived children and their legal guardiancy about the rules and regulations of the Swedish society. Words in GANAP like: "important that newly arrived pupils are given vocational guidance" (p. 28), "information about studies" (p. 3), and "the school also needs to inform the pupils" (p. 28) re-occur in the text pointing to the need of information. This political advice can be grasped as a reversed version of Education about the Other that focuses on providing with knowledge about a marginalized group in order to prevent prejudices, a negative attitude, and silences about that group (Kumashiro, 2000). However, in this case knowledge is about the non-marginalized part, namely the host country directed to a group in risk of being othered.

The question of who is to inform the newly arrived pupil and her or his legal guardian is not clearly stated. The responsibilities of vocational council are explicitly mentioned and are focused upon information regarding vocational choices in relation to education. This can be compared to the risk related to a gap between public- and private sector (see risk e) (Zetterqvist Nelson and Hagström, 2016). This is the only place in the document where the importance to fill this gap is mentioned. Otherwise the term "school" is used when it comes to provide information which can be interpreted as a risk of unclear responsibility division (see risk f) (Zetterqvist Nelson \& Hagström, 2016).

Strategies and responsibilities of various actors in education: Listen to the pupils' views and previous experiences as unique individuals

The analysed document, GANAP includes policy advices for various actors in education that claims as strategy to pay regard to the children's needs to "attend their opinion". The desire to listen to pupils' views and experiences also emerge as a discursive pattern in word combinations like: "[f]undamental requirements to be able to pay regard to the child's best interest are to attend their opinions" (p. 17), "take into account the knowledges and experiences 
that the pupil and legal guardian have" (p. 23), "in dialogue with the pupil" (p. 37), "it is the pupil who chooses" (p. 25), and "[the newly arrived pupil's] knowledges are important to both confirm and take advantage of" (p. 36). This strategy can be compared with Kumashiro's (2000) Education for the Other stressing the necessity to recognize the Other in education, i.e. to listen to them and include there point of view. It is also emphasized in research about immigrant children that their perspectives, ways of being, and view-points need to be acknowledged (see risk c) (Zetterqvist Nelson and Hagström, 2016).

The school has a responsibility to listen to the pupil and pay regard to her or his background knowledge and experiences (GANAP, pp. 17, 23, 25). In a sense that underlines the importance of rendering the pupil visible as a unique individual amongst all actors at school, but on the other hand it opens up a risk that nobody is responsible (see risk f) (Zetterqvist Nelson \& Hagström, 2016). It is however the principle who explicitly is responsible for designing and revising this plan in dialogue with the pupil.

\section{Conclusion and discussion}

Analyzing a policy document highlighting advices how to regard and approach newly arrived pupils' in Swedish education says something significant about desirable directions for action that renders visible both what is included as well as what is excluded in these advices. From an international perspective this can be of value in that it opens up for comparison to how supra national policies for education and immigrants are concretized in a specific country. It needs to be stressed though that it is not possible to draw all-inclusive assumptions about the Swedish policy for newly arrived pupils based on this single document. Rather the study should be regard as a starting point for discussion.

The analysis of the policy document General advices about education for newly arrived pupils (GANAP) indicates that newly arrived pupils are both regarded as unique individuals and as part of a group containing of various sub-groups. The dangers of treating these pupils as a homogenous group is emphasized which harmonizes well with research about opposing violence in general. At the same time the newly arrived children are also described as to have the same rights as other pupils and like children in general be obliged to pay regard the value system and knowledge aims governing education. The advices in the policy have been compared to research about violence, i.e. the seven risks that emanates from research about immigrants in Sweden and Kumashiro's four strategies.

What is particularly payed attention to in the policy document is need to oppose the following risks: b) being in risk of exclusion, c) facing perceptions 
of assimilation, and f) a lack of clear responsibilities amongst the actors assisting the immigrant children. As concerns the desire to establish clear responsibilities it is possible to assert that there is an attempt to render the responsibilities clear but that there also are parts where the responsibility becomes fuzzy. The fuzziness is created with concepts such as "the school should". Moreover, it is vital to point out that the responsibility presented is about accountability and does not involve moral dimensions of responsibility which have been discussed in other contexts (Edling \& Frelin, 2013).

The policy document has touched upon the following risks: e) gap between public- and private sector, g) overlooking the contextual framework that various actors supporting immigrant children take part in. The only time the gap between the public and private is attempted to be filled concerns the vocational council. The responsibility to pay regard to the contextual framework for various actors is merely referred to in terms of the analysis the principle makes about how resources should be divided and how the staff's competences should be developed. Finally, nothing is mentioned about the dangers of a) psychical violence of waiting for the long asylum process to end and the risk of forgetting the need of children with adult guardians. These risks might be payed attention to but is dependent of the knowledge the actors at school have about newly arrived children and violence.

As regards the strategies referred to by Kumashiro Education for the Other is the most dominant one in that the document emphasizes that the newly arrived child's needs in education should be recognized and payed attention to as well as the importance to distribute what is lacking to promote the pupil's development in regards to the value and knowledge assignment. The sustainable dimension present expressed in the strategy Education that changes students and society is acknowledged in the document but the advices from political direction do not say anything in detail about how the Other is to be perceived and how challenges with othering is to be handled. To sum up, the advices for actors in school to approach newly arrived pupils take account of many aspects mentioned as important in research about violence. However it does not say anything about the content of knowledge required amongst various actors in order to do analysis of processes and situations. And knowledge matter!

\section{References}

Åhlund, A. (2015). Swedish as multiparty work: Tailoring talk in a second language classroom. University of Stockholm, Stockholm.

Allport, G.W. (1954). The Nature of Prejudice. Reading, MA: Addison-Wesley.

Andersson, H., Ascher, H., Björnberg, U. \& Eastmond, M. (2010). Mellan det förflutna och framtiden: Asylsökande barns välfärd, hälsa och välbefinnande [Between the 
past and the future. Asylum children's welfare, health, and wellbeing]. Göteborg: Centrum för Europaforskning.

Ascher, H. \& Hjern, A. (2013). Från apati till aktivitet. Teori och behandling av flyktingbarn med svår psykisk ohälsa [From apathy to activity. Theory and treatment of refugee children with sever psych unhealth]. Lund: Studentlitteratur.

Bansel, P., Davies, B., Laws, C. \& Linnell, S. (2009). Bullies, bullying and power in the contexts of schooling. British Journal of Sociology of Education, 30(1), 59-69.

Bunar, N. (2010). Nyanlända och lärande. En forskningsöversikt om nyanlända elever i den svenska skolan. Vetenskapsrådets rapportserie (vol. 6). Stockholm: Vetenskapsrådet.

Bunar, N. (2015). Nyanlända och lärande - mottagande och inkludering. Stockholm: Natur \& Kultur.

Çelikaksoy, A. \& Wadensjö, E. (2016). Hur har de ensamkommande barnen det i Sverige? [How is life for children who seek asylum alone in Sweden?]. Socialmedicinsk tidskrift, 93(1), 28-36.

Eastmond, M. \& Ascher, H. (2011). In the Best Interest of the Child? The Politics of Vulnerability and Negotiations for Asylum in Sweden. Journal of Ethnic and Migration Studies, 27(8), 1185-1200.

Edling, S. (2009). Ruptured narratives: an analysis of the contradictions within young people's responses to issues of personal responsibility and social violence within an educational context. Diss. Uppsala: Acta Universitatis Upsaliensis (AUU).

Edling, S. \& Frelin, A. (2013). Doing good? Interpreting teachers' given and felt responsibilities for the pupil's well-being in an age of measurement. Teachers and teaching: Theory and practice, 19(4), 419-432.

Ekerwald, H. \& Säfström, C.A. (2012). Levd demokrati?: skola och mobbning $i$ ungdomars liv. Stockholm: Liber.

Ellsworth, E. (1989). Why doesn't this feel empowering? Working through the repressive myths of critical pedagogy. Harvard Educational Review, 59, 297-324.

Epp, J. \& Watkinsson, A.M. (1997). Systematic Violence in Education: Promise Broken. New York: State University of New York Press, Albany.

Giroux, H.A. (1988). Teachers as intellectuals: Towards a critical pedagogy of learning. Westport, CT: Bergin \& Garvey.

Greeff, P. \& Grobler, A. (2008). Bullying during the intermediate school phase. Childhood, 15(1), 127-144.

Hamby, S. \& Grych, J. (2013). The Web of Violence Exploring Connections Among Different Forms of Interpersonal Violence and Abuse. New York, London: Springer Dordrecht Heidelberg.

Hertting, K. \& Karlefors, I. (2013). Sport as a Context for Integration: Newly Arrived Immigrant Children in Sweden Drawing Sporting Experiences. International Journal of Humanities and Social Science, 3(18), 35-44.

Hertzberg, F. \& Sundelin, Å. (2014). Counseling between recognition, justice and difference: the significance of power asymmetries, communicative projects and unintended consequences in career counseling of immigrants in Sweden. International Journal for Educational and Vocational Guidance, 14(1), 89-102.

Hooks, B. (1990). Yearning: race, gender, and cultural politics. Boston: South End Press. 
Ketschau, J. \& Thilo (2015). Social Justice as a Link between Sustainability and Educational Sciences. Sustainability 2015, 7, 15754-15771.

Kumashiro, K. (2000). Towards a Theory of Anti-Oppressive Education. Review of Educational Research, 70(1), 25-53.

Kumashiro, K. (2001). Troubling intersections of race and sexuality: queer students of color and anti-oppressive education. Lanham, Md.: Rowman \& Littlefield Publishers.

Miller, A. (2002). For Your Own Good: Hidden Cruelty in Child-Reating, and the Roots of Violence (5 edition). Frankfurt, New York: Suhrkamp Verlag.

Mouffe, C. (2000). The Democratic Paradox. London, New York: Verso.

Nussbaum, M.C. (2012). The new religious intolerance: overcoming the politics of fear in an anxious age. Cambridge, Mass.: Belknap Press of Harvard University Press.

Parkes, J. (2007). The multiple meanings of violence. Children's talk about life in a South African neighbourhood. Childhood, 14(4), 401-414.

Pinar, W. (2007). Introduction. A Queer Conversation, Toward Sustainability. In N. Rodrigues \& W. Pinar (Eds.), Queering Straight Teachers. Discourse and Identity in Education. New York: Peter Lang Publishing.

SFS (2008:567). Diskrimineringslag.

SFS (2010:800). Skollag.

The Swedish National Agency of Education. (2016). Utbildning för nyanlända elever. Skolverkets Allmänna Råd med kommenterar [Education for newly arrived pupils. Advices from the Swedish Board of Education with comments]. Stockholm: Skolverket.

UNHCR (2011). The 1951 convention relationg to the status of refugees and its 1967 protocol. http://www.unhcr.org/about-us/background/4ec262df9/1951-conventionrelating-status-refugees-its-1967-protocol.html [160606].

UNHRC, The UN Refugee Agency. (2016). Figures at the Glance. http://www.unhcr. org/uk/figures-at-a-glance.html [170203].

Waghid, Y. \& Nuraan, D. (2013). Citizenship, education, and violence. On disrupted potentialities and becomings. Rotterdam, Boston, Taipai: Sense Publishers.

Walkerdine, V. (1989). Femininity as Performance. Oxford Review of Education, 15(3), 267-279.

van Dijk, T.A. (1995). Aims of Critical Discourse Analysis. Japaneese Discourse, 1, 17-27.

Wernesjö, U. (2014). Conditional belonging. Listening to unaccompanied young refugees' Voices. Uppsala University, Uppsala.

Young, I.M. (1990). Justice and the politics of difference. Princeton, N.J.: Princeton Univ. Press.

Zetterqvist Nelson, K. \& Hagström, M. (2016). Nyanlända barn och den svenska mottagningskulturen. Röster om hösten 2015 och en kunskapsöversikt [Newly arrived children and the Swedish culture of welcoming. Voices about the autumn 2015 and a knowledge overview]. http://forte.se/wp-content/uploads/2016/06/ nyanlanda-barn-och-den-svenska-mottagningsstrukturen.pdf.

Žižek, S. (2008). Violence. Six sideway reflections. Macmillan. 